\title{
The End of the Cold War, International Disorder, and Refugees: Laying the Foundations for a "New Wall?"
}

\begin{abstract}
Albrecht Schnabel ${ }^{1}$
The hope and anticipation of a better and more just world that was felt during the exhilarating days in 1989 , when the Berlin Wall came down, have soon turned into melancholy. The post-Cold War world is now faced with spreading international disorder, ethnic, civil, and interstate war, a widening gap between the richer and the poorer regions of the world and, consequently, a rapidly increasing number of political, ethnic, environmental, and economic refugees.

Following the end of the Cold War and the breakup of the former Soviet Union, many societies released into independent statehood struggled to regroup themselves within and outside of artificially created post-World War II states. Ethnic minorities have fallen prey to revived ethno-nationalism, and many people have sought refuge from persecution and displacement in Western European countries. Applications for asylum have skyrock-

pects for South-North migration, primarily driven by a potentially explosive population growth, will give this refugee crisis a degree of permeance beyond the scope of the current refugee flows from Eastern and Central Europe.

$\mathrm{A}$ brief look at the German and European restrictive and exclusionary approaches indicates that the industrialized world appears to have found a defense against the effects of growing refugee populations: physical and legal walls directed at controlling and reducing the number of asylum claimants. The results are disastrous for refugees, for the future of international refugee law and, as will be argued, for the long-term security interests of refugee receiving nations. There are solutions beyond fortification against anticipated refugee inflows, alternatives which deserve closer consideration if the refugee problem is to be dealt with effectively.
\end{abstract} eted between 1989, the year the Berlin Wall came down, and the end of 1992. Domestic dissatisfaction in many receiving countries has caused governments to implement revised, much stricter interpretations of previous refugee policies. At the same time, attempts at the European level to either solve ethnic conflicts, or effectively to assist endangered nations in dealing with the tremendous political and economic difficulties responsible for much of their internal instability, have all but failed. Old conflicts are continuing, new ones could break out at any time, and Western Europe is watching in a surprising state of indifference and paralysis. At the same time, the pros-

\footnotetext{
Albrecht Schnabel is a PhD candidate at the Department of Political Studies and Centre for International Relations, Queen's University,
} Kingston, Ontario.

\section{Migration Explosion}

Generally, one can distinguish between three major groups of refugees-Convention refugees, economic refugees, and environmental refugees. Within each group, one has to distinguish between international refugees who seek refuge in foreign countries, and those who are internally displaced, seeking refuge in other parts of their home country. The projections of the potential magnitude of international forced migration are staggering. The explosion of ethnic and nationalist conflicts in many parts of the world, deepening economic divisions between the developed and the developing worlds, and compounding effects of worldwide environmental degradation, force more and more people whose basic existence is endangered to leave their traditional homes for a safe haven elsewhere. As technological de- velopments in the global transportation network make migration over long distances much easier, greater portions of the roughly two-thirds of all refugees, who normally emigrate from one Third World country into another, instead find their way to First World nations. This also allows greater numbers of internally displaced people to cross the borders of their home countries, adding to the increasing pool of international refugees. As well, many countries have broadened the relatively strict definition of Convention refugees, the only category of refugee which is eligible for asylum. This is evident in the rising number of de facto refugees, i.e., persons who are not granted refugee status, but who are also not deported for humanitarian reasons and who, in many cases (e.g. in Germany), represent a much larger group than genuine Convention refugees.

The number of those who are considered refugees under the $1951 \mathrm{Ge}-$ neva Refugee Convention has been rising steadily in the last two decades. After the number of Convention refugees in Europe actually fell from 644,424 in 1970 to 580,000 in 1980 , it increased to 830,000 in 1990, and then exploded to 4,407,461 in 1992. On a global scale, the volume of Convention refugees has increased from 2.4 million in 1970 , to 7.4 million in 1980 , to a staggering 17.2 million in 1990 , and 18.8 million by the end of 1992 (Opitz 1994, 2-3). An additional 24 million people are internally displaced, primarily within Third World countries (US Committee for Refugees 1993). As previously seemingly peaceful and integrated societies are erupting in an explosion of nationalism and ethnic self-determination, national and ethnic conflict is spreading at a frightening rate (Etzioni 1992; Smith 1993). Identities are being reinvented and re- 
experienced at the cost of peace, security, and the very survival of innocent populations caught in the struggles for independence and nationhood. The conflict in the former Yugoslavia (or, most recently, the civil war in Rwanda) illustrates the tragic dimensions of ethnic warfare. More than two million people have been displaced by the various civil and interstate conflicts within and between the successor republics of Yugoslavia alone-a horrible experience which could be repeated throughout the vanished Soviet Empire or other parts of the world (Basok and Benifand 1993; Carter et al. 1993; MacFarlane 1992).

The number of economic refugees who escape poverty and life-threatening conditions in their home regions is much larger than the number of Convention refugees. As economic migrants cannot officially apply for Convention refugee status, and many countries are restricting other legal means for immigration, the only possible venue is illegal migration. Rough estimates suggest that there are about 20 million legal and as many as 100 million illegal economic migrants worldwide (Opitz 1994, 4). The driving force of economic migration can be traced to the world's rapidly growing population which, according to a recent report by the United Nations Population Fund (UNPF), "is the most dominant feature of global demographics" $(1993,1)$. The 1993 global population of 5.57 billion is projected to increase to 6.25 billion by the year $2000,8.5$ billion by 2025 , and 10 billion by 2050 . Rapid growth is expected to continue until the year 2150 , with an estimated global population of 11.6 billion people. Until the end of this century, the developing countries' proportion of this increase will be 95 percent. According to UNPF, by far the fastest rates of growth are in the poorest countries $(1993,1)$. Over the next 20 years, the labour force in developing countries is projected to increase by 730 million, which is 144 million more than today's total labour force of the industrialized world (Purcell, Jr. 1993, 216). Population growth in developing nations will lead to increased urbanization and perpetual poverty, while poverty-stricken rural populations will be growing due to the diminishing ability of cities to provide better living conditions. The potential for dramatically increasing numbers of economic migrants is preprogrammed by this bleak outlook on the evolving structure of the world's population. Hence, as "the developing world remains caught in its poverty trap, the more developed countries will come under siege from tens of millions of migrants and refugees eager to reside among the prosperous but aging populations of the democracies ... [and] ... the results are likely to be painful for the richest one-sixth of the earth's population that now enjoys a disproportionate fivesixths of its wealth" (Kennedy 1993, 46).

Moreover, as growing populations accelerate environmental degradation, environmental refugees will likely become the largest group of forced migrants in the years to come. It is very difficult to provide reliable data on the magnitude of this group of refugees. However, estimates by the International Red Cross consider approximately 500 million people to be environmental refugees, while 600 to 700 million people are believed to live in ecologically endangered areas (Opitz 1992, 32). These long-term speculations on economic and environmental migrants are, in turn, compounded by political and military conflicts (which are likely to proliferate as a result of swelling populations and economic hardship-a vicious cycle with tragic consequences). Consequently, the "century of the refugee" (Arnold, 1991) may have just begun and, in absence of dramatic ecological and economic improvements in the developing world, and a foreseeable stabilization of interethnic relations in the many multinational societies around the globe, the wealthy and politically stable nations in the North and the West will face the challenge of an overwhelming flood of refugees. This will be even more so as the definition of refugee status is gradually being broadened to include those whose lives are endangered by poverty and environmental degradation. Even if not officially recognized, poverty and environmental degradation will indirectly bolster refugee flows, as they will most certainly be the grounds for proliferating ethnic and political conflict over increasingly scarce resources.

\section{International Disorder and East- West Migration}

During the decades following the end of World War II, the bipolar superpower rivalry governed much of the political activity in the international system. Each superpower was preoccupied with keeping its allies in line, and international institutions and regimes were devoted to the prevention of a possible superpower confrontation and the threat of all-out nuclear war. In the 1980s, détente replaced the concept of peaceful coexistence and, apart from the enormous economic strain imposed by a seemingly infinite arms race, the world was a fairly safe place. Some argue that the world was a better place in those times (LynnJones, 1991), during which the lines of allegiance were clearly drawn, and lower level conventional wars on the European continent were effectively prevented by the fear of a potential escalation to a nuclear confrontation.

International security was promoted through regional and international organizations by carefully preserving the integrity of all (major) states involved. The "myth" of the nation-state had been especially successful in Eastern Europe, where socialism, totalitarianism, and centrally executed appeasement of historically diversified communities seemed to have solved the problem of ethnic diversity and ethnic conflict. This myth portrayed a world of internally integrated states, ready to integrate at a larger, international level once the constraints of bipolarity were removed. Interdependence between states was already challenging traditional perceptions of sovereignty, and regional constructs, such as the emerging European Economic Community, served as striking

Refuge, Vol. 14, No. 4 (Aug.-Sept. 1994)) 
examples of transnational integrative movements. Hopes for international cooperation and integration were high during the months immediately following the fall of the Berlin Wall, during the relatively peaceful movement toward democracy and self-rule in many parts of Eastern and Central Europe, and in the wake of the eventual demise of the Soviet empire.

It did not take long, however, before initial hope and joy had subsided. The disappearance of the constraining effect of the Cold War on the actions of individual states and subnational groups would soon bear bitter fruit. Ethnic conflicts and secessionist movements in Europe and elsewhere have turned the immediate post-Cold War period not into an era of integration but, as noted by one observer, into a possible "return to the Middle Ages" (Hassner 1993, 53). As existing state structures are being dismantled and new states are being created based on old and "re-remembered" allegiances and ethnic belonging, as deep seated and well preserved ethnic and nationalist struggles are breaking open after years of suppression, the European continent is emerging from this short moment of liberation and reconciliation as a place of chaos, disorder, and uncertainty.

The end of the Cold War has created many hopes for a better and more prosperous Europe. However, there is a large political, economic, and social price tag attached to the realization of these hopes. The struggling new Germany could well serve as a microcosm of the new Europe. In both cases, a reasonably prosperous, stable, and secure community reached out to embrace its partners to the East. In both cases, migration has played-and continues to play-an important role in the decision-making process of the West, emphasizing the potential danger for states and societies on both sides if separation endures, and gaps in military and economic security between East and West widen even further. Westward migration from Eastern European countries will continue to weaken these already fragile societies and increase domestic pressures in Western Europe. If Western Europe chooses to close its gates to the East, the two regions will drift even further apart, a dangerous approach considering the impact a permanent split of Eastern and Western Europe would have on the security of the European continent.

\section{The Potential Threat from the South}

While the primary cause for East-West migration can be found in ethnic intrastate conflict and the slow economic recovery after decades of planned marked economy, the challenges posed by population growth are likely to be the greatest force driving SouthNorth migration. Thus, while Eastern Europe's population will increase from 96.9 million to 107.2 million by 2025, and the population of the Commonwealth of Independent States (CIS) will grow from 284.5 to 344.5 million, the population of the six North African states will almost double in the same period-from 147.7 million to 280.4 million (UNPF 1993). This unprecedented population growth accelerates the depletion of basic resources, such as water and arable land, and contributes to growing unemployment. The consequences are twofold: economic and environmental migration toward the North will thrive, and increasing political destabilization and military conflict will add to the number of Convention refugees seeking asylum in other parts of the world. While the current pressures of population movements are most intense at Europe's Western borders, they will soon shift southward. Hence, the challenges which Germany is facing today will soon be faced by France, Italy, or Spain. In anticipation of the wave of South-North migration, the restrictive measures recently adopted by countries such as Germany have been promoted in these countries as well. In the case of France, this includes a drastic reduction in legal immigration from Northern Africa. ${ }^{2}$ However, as official immigration policies are tightened, more people will attempt to enter as either asylum seekers, or as illegal immigrants.

\section{Germany's New Refugee Policy}

Germany's experience illustrates the domestic impact which an uncontrolled and rapidly growing influx of refugees-and foreigners in generalcan have on societies of receiving countries. The degree of domestic violence and politicization surrounding the refugee issue in Germany might be replayed in other countries faced with similar domestic pressures. Certainly, the German situation is unique because of the difficulties associated with the process of unification. The broader Western European approach, however, suggests a much more widespread phenomenon. Refugees are no longer welcomed in situations where they pose a threat to the security of receiving countries. The nature or perception of this threat, however, is specific to each country. Germany's geographic proximity to refugee-sending regions, a perceived homoethnic makeup of its society, and the sheer numbers of refugee applicants which had been arriving since 1989 , contributed to the difficulties this country has had in managing its refugee policy (Fijalkowski 1993). The perceived social threat from refugees has been based on a fear of losing the imagined homoethnic fabric of German society, and was articulated in a general discomfort with foreigners, spreading xenophobia and, eventually, physical violence against refugees and other foreigners.

Refugees became scapegoats for many frustrations unleashed by an unhappy unification, a global recession, and a general distrust of government. The political threat, triggered indirectly by rising levels of refugees, had its roots in the social responses to migration-an essentially unnecessary politicization of the refugee issue by traditional political parties, an exacerbation of the security threat caused by growing numbers of foreigners, and the remarkable growth of anti-foreigner movements and political parties (Neckermann 1993). 
A quick and effective response to the refugee threat was soon found. To avert a national crisis, the German government decided to severely restrict one of the world's most liberal asylum policies. The revision of Article 16 (a), Germany's asylum law, now provides the legal justification for a systematic reduction in refugee intake. The new asylum law (Bundesministerium des Innern 1993) includes the following stipulations:

- Refugees can no longer apply for asylum in a member state of the European Union (EU) [formerly the European Community] if already rejected by another member.

- Even though the right to asylum remains a constitutional right, it has now been qualified: foreigners who enter Germany from "safe third countries" - including every country bordering Germany-are excluded from the right to asylum, as they could have found refuge in the first safe country they had entered. ${ }^{3}$

- An expanded list of "safe source countries."

- A fast-track approach (maximum 19 days) for suspected criminals, undocumented aliens, and applicants who have passed through "safe third countries." 4

- Refugees from wars and civil wars will be granted temporary permission to stay in Germany, but will be denied the alternative of applying for permanent asylum. ${ }^{5}$

- Lastly, social benefits for asylum seekers in Germany will be available for a maximum of one year (no limit under the previous law), they will be cut by roughly 15 percent to cover only the minimum in living expenses, and they will be paid out primarily in vouchers rather than in cash amounts.

\section{The European Union-Shifting Borders}

The broader Western European approach looks much the same, having actually predated Germany's asylum policy reforms. A growing "fortress Europe" is preparing itself for a war of an unknown nature and dimensions- a war against immigration of political, economic, and environmental refugees. Foreigners are not welcome anymore, especially if they are poor, undereducated, or of different cultural and ethnic background. Western Europeans are not necessarily turning into racists or humanitarian isolationists, but they are afraid of losing their own particular cultural homogeneity, much of which is already challenged by the European integration process. Suffering from their own economic and societal crises, Western European states have only limited resources avaitable to assist ever growing numbers of displaced persons.

In some Western European countries, formerly exemplary and generous refugee policies have been transformed into sad images of their humanitarian and noble predecessors. Moreover, the refugee issue has turned into a unifying force, as the European Union is in search of measures which will assure that none of its member states will admit "excessive" numbers of refugees which, after all, could be moving unhindered throughout the borderless Union. The adoption of a "harmonized" European Union-wide immigration policy to streamline individual member states' asylum policies will likely be only a matter of time.

The Schengen Agreement of 1985 and its followup, the 1990 Dublin Convention, make it much harder for a potential refugee to enter the territory of the European Union. Refugees must have valid travel documents, and face sanctions if they illegally cross into EU territory. Both these stipulations contravene the Geneva Refugee Convention-refugees rarely have valid travel documents or are granted exit visas by their governments. Additionally, transport companies are liable to stiff penalties for transporting passengers without adequate travel documents and entry visas. Further, once a refugee has actually managed to legally (or illegally) enter an EU member state, it is the sole responsibility of the state of first entry to assess and decide the refugee's claim for asylum. Once rejected, the unsuccessful asylum seeker cannot reapply for asylum in another EU country. Thus, total responsibility for refugees lies within the country of first entry, including the deportation of unsuccessful asylum seekers, even in the case the refugee has in the meanwhile illegally moved on to another member state. Overall, this policy of streamlining the refugee application process across all of the European Union is unfair in the absence of uniform agreements among EU member states on the definition of "refugee" and on national asylum laws. It can be expected that refugees will try to apply for asylum in the country with the most liberal or generous asylum policy. This, however, could lead to a tendency to harmonize national asylum policies according to the lowest common denominator, in an effort to subvert country preferences of incoming refugees and to prevent an unequal distribution of the "refugee-burden" (Fernhout 1993, 499).

National and regional security interests have thus prevailed over international standards on the protection of human and group rights. As industrialized nations are facing increasing challenges to the political and economic security they enjoyed during the Cold Waryears, compassion for the plight of the poor, underdeveloped, or persecuted members of the global community is rapidly shrinking.

\section{The "Fortress"-An Illusory Solution}

The fortification of refugee-receiving countries and regions emerges as a rational and pragmatic approach to contain the social, political, and economic costs of forced migration. Aside from political and financial costs associated with the maintenance and expansion of protective anti-refugee defense mechanisms, this approach offers little more than the illusion of having averted possible security threats to First World societies by Second and Third World nations. The "fortress" approach is paradoxical, since peripheral conflict and crises will continue to threaten regional security, and because illegal migration will increase in

Refuge, Vol. 14, No. 4 (Aug.-Sept. 1994)) 
response to legal and procedural barriers to asylum in the receiving countries. As many immigrants will be forced to go underground, and if conflicts in source countries remain unattended, this approach will, in the long run, most likely exacerbate the problems associated with an escalating refugee crisis. An unwise European migration policy, which intentionally ignores Eastern Europe and Northern Africa's problems by offering purely symbolic tokens of sympathy, is certain to backfire on Western Europe's security.

Migration is a useful measure of Eastern Europe's and Northern Africa's political, economic, and social conditions. Curbing emigration from these countries serves two purposes: it relieves Western European nations from the various pressures and consequences of increased immigration and, especially with regard to Eastern Europe, it defuses the crisis and conflict in the region-overall an advantageous deal for Western Europe, which clearly has greater political and economic resources for resolving this conflict than do its Eastern European neighbours. Simply, it is in the national interest of every industrialized nation to invest in the domestic security of poorer and less stable refugee-sending countries, in order to protect their own security.

\section{Recommendations}

Naturally, it would be in the interest of all parties (refugees, refugee-sending and receiving countries) to reduce the level of forced migration. However, there are other ways for achieving this than the construction of a "New Wall." One approach addresses the systematic reduction of refugee inflows by alleviating the causes of forced migration in source countries, combined with stricter and harmonized refugee determination processes. Initiatives aimed at solutions within refugee source countries should ideally address all of the major groups of forced migrants: the number of traditional political refugees can be reduced through assistance for political reform and democratic restructuring; refu- gees persecuted for belonging to particular ethnic groups can be helped with preventive diplomacy, peacekeeping, or full-fledged humanitarian intervention in ethnic conflict; and the rise of economic and environmental refugees can be confronted with financial, political, and technological assistance to solve or contain economic and environmental crises.

None of the individual root causes for emigration can be viewed in isolation from others, and the composition of refugee groups, as well as the combination of various factors responsible for forced migration, vary from case to case. Thus, each case has to be met with an individual combination of possible root cause solutions. The effect of such outside involvement on a country's political, social, and economic fabric can then be judged by corresponding levels of internal displacement and out-migration. Ideally, the number of refugees seeking refuge in First World countries will decline as a response to limited domestic conflict and crisis in source countries. This will reduce potential security threats to receiving countries' domestic stability and, eventually, it could render unnecessary further fortification against the proliferating refugee problem and regional security threats.

As sociologist Anthony Richmond suggests, "[i]n the postmodern world we must all learn to live with ethnocultural diversity, rapid social change and mass migration - there is no peaceful alternative" $(1993,10)$.

Despite the best intentions at controlling the most prevalent causes of forced migration, however, immediate effects on the levels of refugee movements will likely be marginal. A second approach should thus be directed at continued commitment to current (if not expanded) levels of refugee intake. However, if the domestic instabilities experienced by Germany are to be avoided, it will be necessary to reduce the negative impact of migrants and refugees on receiving societies. This can be achieved through the promotion of increased tolerance for foreigners, promotion of positive con- tributions of refugees to their host societies and of the humanitarian responsibilities of the host society, and by regional distribution schemes that will spread the political and socioeconomic burden of refugee populations equally. A greater prominence given to refugees as part of overall immigration levels-even at the cost of admitting lower levels of business or independent immigrants-would do greater justice to the challenges posed by growing global refugee populations and nations' limited capabilities at integrating considerable numbers of foreigners.

Both external and "homefront" measures, aimed at controlling the negative security impact of refugee movements on receiving societies, would change the population's perception of the social, political, and economic impact of immigration, and offset the negative politicization of refugee issues pursued by right wing movements and parties. "Homefront" measures are inexpensive and quickly initiated, especially when elections are approaching. However, by themselves, they are of only limited value if asylum-seekers continue to arrive in large numbers and no changes in migration patterns are apparent. External measures, on the other hand, are costly, they represent long-term commitments, and they likely require multilateral and international cooperation (Boutros-Ghali 1992; Cox 1993; Huber 1993). A combination of both approaches-promoting tolerance at home, while creating peace and security in refugee source countrieswould be an ideal strategy. Given the preventive nature of attempts at managing the root causes of migration, one can only speculate on the impact of such efforts. However, the lack or inadequacy of preventive measures in recent cases of ethnic civil wars (such as in Yugoslavia or in Somalia), the humanitarian accomplishments of eventual international involvement in these conflicts, and the gradually shrinking levels of out-migration from these regions, suggest the potential merit of such actions. On the other 
hand, continuing refugee flow from places like Haiti and Rwanda, where international responses have been all but adequate in finding solutions to exacerbating crises, demonstrate the consequences of international indifference to crisis and conflict in the periphery.

Admittedly, these suggestions appear to reflect a rather idealistic approach, which does not take into account the difficulties and complexities of having to "sell" a more active and compassionate approach. On the other hand, are there viable alternatives besides shielding oneself off from potential refugee inflows, an approach which does little more than postponing solutions until conditions responsible for population movements have worsened even further? Changing attitudes in refugee-receiving countries toward the realities of growing multiculturalism, and the recognition of the necessity of more active involvement in the solution of refugeecausing conflict and crises, must be promoted-and eventually perceived-as the only viable approaches to the emerging refugee crisis. Otherwise, we will see intensifying refugee pressures from the East and the South, and a growing notion of the permanence of a new Wall characteristic-the emerging exclusionary nature- of the "new Europe."

\section{Notes}

1. The author wishes to express his gratitude to Doug Hall, S. Neil MacFarlane, Kathleen Schnabel and two anonymous reviewers for their insightful comments and suggestions on earlier drafts.

2. For instance, France's Interior Minister Charles Pasqua reportedly committed himself to achieving "zero illegal immigration," while cutting the numbers of legal immigrants in half. This could be done "without harming France's reputation as a country of refuge." Although acknowledging that "zero immigration" would be unachievable, he nevertheless believes that "in a situation of economic crisis, that is what we should be aiming for, to allow the fewest new arrivals as possible, in order not to seriously jeopardize the integration of those who are already here." Reported by AFP, Paris, 1 July 1993, in FBIS-WEU-93-125 (1 July 1993), 42-43.
3. "Cooperation Treaties" for re-deportation procedures of refugees have been concluded with Poland and Switzerland, and are currently being negotiated with the Czech Republic and Austria, all of which are major transit countries for refugees from Eastern and Central Europe. Germany is offering various financial support structures to assist these countries in dealing with the returned refugees (Bundesministerium des Innern, 1993; Frankfurter Allgemeine Zeitung, 1994).

4. This seems to be a particularly poor solution in dealing with refugees who have false documents or no documents at all. Valid exit visas or other official travel documents are often not available to refugees, in which case false documents offer the only viable possibility of leaving the country of origin. In addition, applicants with little or no hard evidence of persecution in their home countries will find it extremely difficult to make a strong case without a reasonable time to properly prepare for such a case. However, German law stipulates that an applicant will be allowed to enter Germany if his or her case cannot be dealt with within 19 days. Obviously, this leaves much clout to the judgement of individual immigration officials, and it can serve as an incentive for dealing with difficult cases in a careless manner.

5. This denounces one of the most endangered groups of refugees - ethnic refugees-as simply "temporary victims of civil wars," a gross misjudgement of the nature and consequences of ethnic conflict.

\section{References}

Arnold, Hans. 1991. "The Century of the Refugee,' A European Century?" Aussenpolitik, March 1991.

Basok, Tanya and Alexander Benifand. 1993. "Recent Political Developments in Russia and Four Types of Potential Refugees." Refuge 13, no. 7 .

Boutros-Ghali, Boutros. 1992. An Agenda for Peace: Preventive Diplomacy, Peacemaking and Peace-keeping. New York: United Nations.

Bundesministerium des Innern (Federal Ministry of the Interior). 1994. "Asylbewerberzahlen fur den Monat Dezember 1993 und für das Jahr 1993." Das Bundesministerium des Innern teilt mit, January 5. 1993. Das Neue Asylrecht. Bonn: Osang Verlag.

Carter, F.W., R.A. French, and J. Salt. 1993. "International Migration Between East and West in Europe." Ethnic and Racial Studies 16 , no. 3.

Cox, David. 1993. Aurora Paper 20, Exploring An Agenda for Peace: Issues Arising from the Report of the Secretary-General. Ottawa: Canadian Centre for Global Security.

Der Spiegel. 1993. "Neuer Vorhang." No. 8, February 22.
Etzioni, Amitai. 1992. "The Evils of Self-Determination." Foreign Policy, no. 89.

Fernhout, Roel. 1993. "'Europe 1993' and Its Refugees." Ethnic and Racial Studies 16, no. 3 .

Fijalkowski, Jurgen. 1993. "Aggressive Nationalism, Immigration Pressure and Asylum Policy Disputes in Contemporary Germany." International Migration Review 27, no. 4.

Frankfurter Allgemeine Zeitung. 1994. "Koalition und SPD fordern 'Bürgerkriegsregelung'." January 13.

Hassner, Pierre. 1993. "Beyond Nationalism and Internationalism: Ethnicity and World Order." Survival 35, no. 2.

Huber, Konrad J. 1993. "The CSCE and Ethnic Conflict in the East." RFE/RL Research Report 2, no. 31 .

Joffe, Josef. 1993. "The New Europe: Yesterday's Ghosts." Foreign Affairs 72, no. 1.

Kennedy, Paul. 1993. Preparing for the TwentyFirst Century. Toronto: Harper Collins.

Loescher, Gil. 1992. "Refugee Movements and International Security." Adelphi Papers 268, Summer.

Lynn-Jones, Sean M., editor. 1991. The Cold War and After: Prospects for Peace. Cambridge, Mass.: MIT Press.

MacFarlane, Neil. 1992. "Crisis and Opportunity in the Republic of Georgia." Canadian Foreign Policy 1, no. 1.

Neckermann, Peter. 1993. "What Went Wrong in Germany After the Unification?" East European Quarterly 26, no. 4.

Opitz, Peter J. 1994. "Weltproblem Migration Neue Dimensionen internationaler Instabilität." Reader Sicherheitspolitik 1-2/94.

Opitz, Peter J. 1992. "Die weltweiten Flüchtlings- und Migrationsbewegungen: Ursachen und Dimensionen." Politische Studien 43, special issue no. 1.

Purcell, Jr., James N. 1993. "Migration Challenges of the 1990s." The World Today 49, no. 11.

Richmond, Anthony H. 1993. "Open and Closed Borders: Is the New World Order Creating a System of Global Apartheid?" Refuge 13, no. 1.

Rosenau, James N. 1990. Turbulence in World Politics: $A$ Theory of Change and Continuity. Princeton, N.J.: Princeton University Press.

Smith, Antony D. 1993. "The Ethnic Sources of Nationalism." Survival 35, no. 1.

United Nations Population Fund. 1993. The State of the World Population. New York: United Nations.

United States Committee for Refugees. 1993. World Refugee Survey 1993. Washington, D.C. כ

CRS publishes Refuge every month, except in July and August. Please ensure your subscription is current. 